\title{
PENYALURAN KREDIT DENGAN EKSISTENSI DANA PIHAK KETIGA
}

\author{
Deden Edwar Yokeu Bernardin \\ Universitas BSI Bandung \\ Deden.dey@bsi.ac.id
}

\section{Iwan Sofyan}

Universitas BSI Bandung

Iwan.ifn@bsi.ac.id

\begin{abstract}
Abstrak
Penelitian ini bertujuan untuk menganalisa penyaluran kredit dengan eksistensi dana pihak ketiga ( tabungan, giro dan deposito), Populasinya annual report Bank BJB dan sampelnya laporan keuangan selama dua belas tahun terakhir dari 2006 sampai 2017 yang diambil dari Bursa Efek Indonesia (BEI). Dengan metode deskriptif verifikatif serta mengunakan data time series. Hasil penelitian menunjukan bahwa penyaluran kredit sangat ditentukan kemampuannya perusahaan dalam penghimpunan dana pihak ketiganya, dari total dana pihak ketiga yang dihimpun selama kurun waktu 2006-2017 dana pihak ketiga dalam bentuk deposito yang nilainya lebih besar tetapi nilai penyaluran kredit ditentukan leh keseluruhan dana pihak ketiga, hasil perhitungan pengaruh menunjukkan dana pihak ketiga merupakan penyumbang utama bagi bank dalam proses penyaluran dana dalam bentuk kredit bagi masyarakat, sehingga semakin besar nilai dana pihak ketiga maka semakin tinggi kemampuan bank dalam menyalurkan kreditnya.
\end{abstract}

Kata Kunci Dana Pihak Ketiga, Penyaluran Kredit

\section{PENDAHULUAN}

Krisis ekonomi yang terjadi tahun 1998 telah mengakibatkan gangguan secara global di seluruh sektor perbankan. Dimana sebagian sektor riil mengalami pertumbuhan yang cenderung negatif bahkan mengalami kebangkrutan. Masyarakat tidak lagi percaya untuk menanamkan modalnya pada sektor perbankan. Tidak terlepas pada sektor perbankan sebagai pemberian kredit, karena nasabah juga mengalami kesulitan dalam mengembalikan kredit yang diterimanya. Hal ini memacu peningkatan jumlah kredit bermasalah serta menurunnya tingkat kepercayaan masyarakat. Sehingga dapat mengganggu aktivitas utama bank sebagai penghimpun dana dan pemberi kredit bagi pihak yang memerlukan.

Namun pada tahun 2016 ini keadaan ekonomi Indonesia lebih baik, dimana Bank Indonesia mencatat penyaluran kredit dari perbankan pada Maret 2016 tumbuh 8,4\% jika dibandingkan Maret 2015, atau meningkat jika dibandingkan pertumbuhan tahunan Februari 2016 yang sebesar 8,1\%. Pertumbuhan 8,4\% Maret secara tahunan itu membuat realisasi penyaluran kredit perbankan mencapai Rp 4.027,2 triliun di bulan ketiga 2016, dikutip dari publikasi statistik uang beredar dalam arti luas (M2) BI di Jakarta (Baihaqi, 2016).

Bank sentral menilai pertumbuhan saluran kredit itu karena transmisi pelonggaran kebijakan moneter dengan penurunan suku bunga acuan BI (BI rate) 75 basis poin sejak Januari 2016, dan penurunan Giro Wajib Minimum Primer sebesar 150 basis poin sejak Desember 2015. Pertumbuhan kredit perbankan itu akhirnya memicu pertumbuhan uang beredar dalam arti luas (M2) di Maret 2016 yang tumbuh 7,4\%, lebih tinggi dibandingkan Februari 2016 yang sebesar 7,2\%.

BI mencatat akselerasi pertumbuhan kredit dipengaruhi pertumbuhan Kredit Modal Kerja (KMK) sebesar 6,3\% menjadi sebesar Rp 1.846,9 triliun. "Pertumbuhan KMK itu dipicu saluran kredit untuk industri pengolahan yang tumbuh $4,8 \%$ serta sektor perdagangan, hotel, dan restoran (PHR) yang tumbuh $7,8 \%, "$ tulis BI (Baihaqi, 2016).

Namun, pertumbuhan untuk kredit investasi yang dipinjam industri pengolahan dan PHR justru melambat, masing-masing sebesar 14,4\% dan 11,7\% pada Maret 2016 dari 16,6\% dan 13,2 \% di Februari 
2016. Untuk pertumbuhan kredit Usaha Mikro, Kecil, dan Menengah (UMKM) juga melambat menjadi 7,8\% atau sebesar Rp 738,0 triliun dibandingkan Februari 10\% (Baihaqi, 2016).

Sementara itu, pertumbuhan penyaluran kredit pada sektor properti relatif stabil, dengan realisasi Rp 623,8 triliun atau tumbuh sebesar 11,4\% seperti pada Februari. BI juga mendeteksi penurunan suku bunga kredit sebesar 9 basis poin menjadi 12,7\% per Maret dibandingkan Februari sebesar 12,79\%. Untuk suku bunga simpanan berjangka 1, 3, 6, dan 12 bulan tercatat masing-masing sebesar 7,06\%, 7,75\%, 8,31\%, dan $8,19 \%$, turun dibandingkan bulan sebelumnya yang sebesar 7,32\%, 7,97\%, 8,43\% dan $8,40 \%$. (Baihaqi, 2016)

Dalam rangka pembiayaan kegiatan perekonomian untuk mendorong pertumbuhan ekonomi yang cukup tinggi, pemberian kredit perbankan mempunyai peranan yang penting. Pemberian kredit dalam masyarakat mempengaruhi tingkat pertumbuhan ekonomi, dimana salah satu indikasi dari kemajuan perekonomian suatu daerah adalah melalui tingkat pemberian kredit dalam masyarakat. Berdasarkan berita di atas, fungsi intermediasi perbankan terus meningkat, hal ini ditunjukkan dengan tumbuhnya pemberian kredit dari 8,1\% pada Februari 2016 menjadi 8,4\% pada Maret 2016. Dengan tumbuhnya kredit modal kerja (KMK) sebesar 6,3\% menunjukkan peranan kredit bank dalam dunia usaha sangatlah penting, karena sebagian besar didanai oleh kredit bank. Sehingga para pelaku usaha lebih mengandalkan bantuan kredit untuk investasi maupun untuk modal kerja dibandingkan dengan modal sendiri.

Pemberian kredit perbankan di dalam mendorong pertumbuhan ekonomi dapat berarti penciptaan lapangan kerja, baik melalui perluasan produksi dan kegiatan usaha lainnya maupun melalui pengaruhnya dalam mendorong munculnya unit- unit usaha baru. Selain itu, kredit perbankan dapat diarahkan untuk pemerataan kesempatan berusaha yang antara lain melalui alokasi pemberian kredit maupun prioritas pembangunan dan golongan ekonomi sehingga pada gilirannya dapat memperluas pemerataan hasil-hasil pembangunan.

Menurut Ikatan Bankir Indonesia dan Lembaga Sertifikasi Profesi Perbankan (2013:114) kredit adalah penyediaan dana atau tagihan lain yang sejenis hal itu, berdasarkan persetujuan atau kesepakatan pinjam-meminjam antara bank dengan pihak lain yang mewajibkan pihak peminjam untuk melunasi utangnya setelah jangka waktu tertentu dengan pemberian bunga.

Berdasarkan pengertian di atas, kredit terdiri dari beberapa unsur diantaranya jangka waktu dan bunga. Setiap kredit yang diberikan pasti memiliki jangka waktu tertentu, jangka waktu ini mencakup masa pengembalian kredit yang telah disepakati oleh bank sebagai kreditur dan penerima kredit sebagai debitur. Sedangkan bunga merupakan suatu keuntungan atas pemberian suatu kredit atau jasa. Hal ini merupakan akibat dari pemberian fasilitas kredit, bank tentunya mengharapkan suatu keuntungan dalam jumlah tertentu. Pemberian kredit yang dilakukan oleh bank mengandung risiko salah satunya adalah kredit tidak tertagih. Hal ini disebabkan karena adanya suatu tenggang waktu pengembalian (jangka waktu), dimana semakin panjang jangka waktu suatu kredit maka semakin besar risikonya tidak tertagih, demikian pula sebaliknya dan risiko ini menjadi tanggungan bank. Peranan bank sebagai lembaga keuangan tidak pernah lepas dari masalah kredit. Bahkan, kegiatan bank sebagai lembaga keuangan pemberian kredit merupakan kegiatan utamanya.

Salah satu cara bank dalam menghimpun dana pihak ketiga adalah dalam bentuk simpanan (rekening) tabungan. Simpanan tabungan digunakan untuk umum dan lebih banyak digunakan oleh perorangan baik pegawai, mahasiswa atau ibu rumah tangga. Bagi mereka yang menyimpan uangnya di rekening tabungan di samping kemudahan untuk mengambil uangnya juga adanya pengharapan bunga yang lebih besar jika dibandingkan dengan rekening giro.

Menurut Rivai et al (2013:174) tabungan adalah simpanan dana pihak ketiga dalam rupiah dan atau valuta asing pada bank yang penarikannya hanya dapat dilakukan menurut syarat tertentu dari masingmasing bank penerbit, tetapi tidak dapat ditarik dengan cek, bilyet giro atau alat lainnya yang dapat dipersamakan dengan itu.

Berdasarkan pengertian diatas, simpanan tabungan mempunyai syarat-syarat tertentu bagi pemegangnya dan persyaratan masing-masing bank berbeda satu sama lainnya. Di samping persyaratan yang berbeda, tujuan nasabah menyimpan uang di rekening tabungan juga berbeda. Dengan demikian bank memasarkan produknya juga berbeda sesuai dengan sasarannya.

Sumber dana merupakan hal terpenting bagi bank untuk dapat meningkatkan jumlah kredit yang akan diberikan kepada masyarakat, sehingga bank memerlukan ketersediaan sumber dana. Semakin banyak dana yang dimiliki oleh bank, maka akan semakin besar peluang bank untuk menjalankan fungsinya.

Faktor sumber dana bank merupakan faktor yang penting bagi bank dalam rangka mengembangkan usaha serta menanggung risiko kerugian yang diderita. Pos-pos modal dan simpanan dana pihak ketiga merupakan kekuatan pokok yang mencerminkan potensi bank yang bersangkutan. Modal inilah yang 
merupakan motor penggerak bank sebagai perusahaan dalam mencapai tujuan sehingga kemajuan bank banyak tergantung dari pos-pos ini.

Sumber dana yang dapat digunakan untuk pembiayaan adalah modal sendiri yang terdiri dari modal disetor para pemegang saham, laba ditahan dan cadangan- cadangan. Menurut Karim dalam Pratin dan Adnan (2005:38) salah satu sumber dana yang bisa digunakan pembiayaan (loan) adalah modal sendiri, sehingga semakin besar sumber dana yang ada maka bank akan dapat menyalurkan pembiayaan dalam batas maksimum yang lebih besar pula.

Dari uraian-uraian dan fenomena diatas dapat dilihat sangat besarnya arti penyaluran kredit bagi usaha masyarakat, hal tersebut akan terjadi kelancaran bila disokong dengan kestabilan keuangan dari perbankan dimana dana pihak ketiga menjadi hal yang paling utama dalam menunjang goingconcern bank. Juga dalam hal ini provinsi jawabarat mempunyai bank yaitu bank bjb yang terus berkembang dari tahun ketahun sehingga menjadi salah satu bank pemerintah daerah yang tersebar seluruh indonesia. Maka dari hal-hal tersebut penelitian ini akan terfokus pada penyaluran produk kredit dengan eksistensi dana pihak ketiga bank guna menunjang sektor umkm.

\subsection{Perumusan Masalah}

Dengan keadaan situasi Jawa Barat yang menjadikan salah satu kota pariwisata dan didorong banyaknya sumber pendapatan dari sektor bisnis yang mendukung kota pariwisata maka dibutuhkan dana dalam menunjang hal tersebut, menjadi menarik untuk diketahui kempampuannya bank dalam menunjang penyaluran kredit bagi pegiat usaha yang ada, Bertitik tolak dari latar belakang masalah yang menjadi masalah dalam penelitian ini adalah sebagai berikut:

Permasalahan yang hendak diuji dalam penelitian ini dapat dirumuskan sebagai berikut:

1. Bagaimana Dana Pihak Ketiga (DPK) pada Bank BJB yang terdaftar di BEI?

2. Bagaimana Penyaluran kredit pada Bank BJB yang terdaftar di BEI?

3. Seberapa besar pengaruh dana pihak ketiga terhadap penyaluran kredit pada Bank BJB yang terdaftar di BEI?

\section{II.LANDASAN TEORI}

\section{Bank}

Menurut Kasmir (2012:12) bank adalah lembaga keuangan yang kegiatan utamanya menghimpun dana dari masyarakat dan menyalurkan kembali dana tersebut ke masyarakat serta memberikan jasa bank lainnya.

Berdasarkan Undang-Undang No. 10 Tahun 1998 tentang Perbankan:

"Bank adalah badan usaha yang menghimpun dana dari masyarakat dalam bentuk simpanan dan menyalurkannya kepada masyarakat dalam bentuk kredit dan atau bentuk-bentuk lainnya dalam rangka meningkatkan taraf hidup rakyat banyak."

\section{Dana Pihak Ketiga (DPK)}

Menurut Rivai et al 2013:172) dana pihak ketiga (DPK) atau dana masyarakat adalah dana yang diperoleh dari masyarakat, dalam arti masyarakat sebagai individu, perusahaan, pemerintah, rumah tangga, koperasi, yayasan dan lain-lain, baik dalam mata uang rupiah maupun dalam valuta asing.

Untuk menghimpun dana dari masyarakat bank dapat menggunakan tiga macam jenis simpanan (rekening), dimana masing-masing jenis simpanan memiliki keunggulan tersendiri sehingga bank harus pandai dalam menyiasati pemilihan sumber dana. Pembagian jenis simpanan ke dalam beberapa jenis dimaksudkan agar nasabah mempunyai pilihan sesuai dengan kebutuhan dan tujuan masing-masing. Menurut Kasmir (2012:53) sumber-sumber dana dari masyarakat berasal dari:

a. Giro adalah simpanan yang penarikannya dapat dilakukan setiap saat dengan menggunakan cek, bilyet giro, sarana perintah pembayaran lainnya atau dengan cara pemindahbukuan. Simpanan giro biasanya digunakan oleh para pengusaha atau para pedagang dalam bertransaksi. Keuntungan rekening giro adalah kemudahan dalam melakukan pembayaran, terutama bagi mereka yang berkecimpung di dunia bisnis walaupun bunganya relatif kecil.

b. Tabungan adalah simpanan yang penarikannya hanya dapat dilakukan menurut syarat-syarat tertentu yang disepakati, tetapi tidak dapat ditarik dengan cek, bilyet giro dan/atau alat lainnya yang dipersamakan dengan itu. Simpanan tabungan digunakan untuk umum dan lebih banyak 
digunakan oleh perorangan baik pegawai, mahasiswa, atau ibu rumah tangga. Simpanan tabungan memiliki bunga ynag lebih tinggi dari jasa giro yang diberikan kepada nasabah.

c. Deposito adalah simpanan yang penarikannya hanya dapat dilakukan pada waktu tertentu berdasarkan perjanjian nasabah penyimpan dengan bank. Dana yang berasal dari deposito adalah dana termahal yang harus ditanggung oleh bank. Karena suku bunag yang relatif lebih tinggi dari kedua jenis simpanan sebelumnya. Dana dari simpanan pada umumnya dihimpun dari pengusaha menengah dan masyarakat dari golongan menengah atas yang bukan bisnis.

\section{Kredit}

Menurut Dendawijaya dalam Sari (2013:933) dana-dana yang dihimpun dari masyarakat merupakan sumber dana terbesar yang paling diandalkan oleh bank bisa mencapai 80\%-90\% dari seluruh dana yang dikelola oleh bank. Sebagai lembaga keuangan yang memiliki fungsi intermediasi, bank mengelola dana yang dihimpunnya dari masyarakat kemudian menyalurkannya kembali kepada masyarakat. Oleh karena itu, semakin besar dana pihak ketiga yang bisa dihimpun maka peran bank untuk meyalurkan dana tersebut juga semakin besar, terutama dalam pemberian kredit.

Menurut Kasmir (2015:58) dana untuk membiayai operasi dapat diperoleh dari berbagai sumber. Perolehan dana ini tergantung bank itu sendiri apakah secara pinjaman (titipan) dari masyarakat atau dari lembaga lainnya. Disamping itu untuk membiayai operasinya dana dapat pula diperoleh dengan modal sendiri, yaitu dengan mengeluarkan atau menjual saham. Perolehan dana disesuaikan dengan tujuan dari penggunaan tersebut.

Dana yang diperoleh bank dalam simpanan disalurkan kembali dalam bentuk kredit kepada masyarakat yang memerlukannya. Bank akan memperoleh keuntungan dari selisih bunga yang diberikan kepada masyarakat. Menurut Tucker dalam Latumaerissa (2014:119) mengemukakan bahwa "kredit adalah perpindahan suatu yang berharga kepada orang lain, baik berupa uang, barang ataupun jasa-jasa, dengan keyakinan bahwa ia akan berkemauan dan berkemampuan untuk membayar imbangannya pada suatu hari mendatang."

Berdasarkan Undang- Undang No. 10 tahun 1998 tentang Perbankan:

"Kredit adalah penyediaan uang atau tagihan- tagihan yang dapat disamakan dengan itu berdasarkan persetujuan atau kesepakatan pinjam meminjam antara bank dengan pihak lain yang mewajibkan pihak peminjam untuk melunasi hutangnya setelah jangka waktu tertentu dengan pemberian bunga."

\section{METODOLOGI PENELITIAN}

Dalam penelitian ini penulis menggunakan metode deskriptif dan verifikatif dengan pendekatan kuantitaif. Data yang digunakan dalam penelitian ini adalah data sekunder. Teknik pengumpulan data yang digunakan yaitu metode observasi dan studi pustaka. Populasi yang digunakan dalam penelitian adalah Laporan Keuangan Publikasi Bank BJB. Sampel yang digunakan untuk penelitian ini meliputi periode 2006-2017. Teknis analisis data yang digunakan menurut Sugiyono (2014) adalah : (1) Uji Asumsi Klasik; (2) Uji Korelasi; (3) Uji Hipotesis; (4) Koefisien Determinasi dengan teknik regresi sederhana menggunakan Software SPSS versi 20.

\section{HASIL PENELITIAN}

\subsection{Hasil Penelitian}

\subsubsection{Analisis Deskriptif}

Dalam melakukan penelitian penyaluran kredit dengan eksistensi dana pihak ketiga Bank BJB periode 2010 - 2016, penelitian ini memperoleh data dari Bursa Efek Indonesia dan BPS kota bandung, dengan rincian data pertahunnya sebagai berikut:

Tabel IV.1

Data Variabel dari Tahun 2010 s.d 2016

\begin{tabular}{|c|c|c|c|c|c|}
\hline $\begin{array}{c}\text { TAH } \\
\text { UN }\end{array}$ & $\begin{array}{c}\text { DPK } \\
\text { (Tabungan) }\end{array}$ & DPK (Giro) & DPK (Deposito) & Total DPK & $\begin{array}{c}\text { Penyaluran } \\
\text { Kredit }\end{array}$ \\
\cline { 2 - 6 } & $\begin{array}{c}\text { (dalam jutaan } \\
\text { rupiah) }\end{array}$ & $\begin{array}{c}\text { (dalam jutaan } \\
\text { rupiah) }\end{array}$ & $\begin{array}{c}\text { (dalam jutaan } \\
\text { rupiah) }\end{array}$ & $\begin{array}{c}\text { (dalam jutaan } \\
\text { rupiah) }\end{array}$ & $\begin{array}{c}\text { (dalam jutaan } \\
\text { rupiah) }\end{array}$ \\
\hline 2006 & 2172886 & 6621528 & 6746412 & 15540826 & 11763535 \\
\hline
\end{tabular}




\begin{tabular}{|l|l|l|l|l|l|}
\hline 2007 & 2709291 & 6563062 & 7213029 & 16485382 & 13047515 \\
\hline 2008 & 3139322 & 7405206 & 7802522 & 18347050 & 16429069 \\
\hline 2009 & 3802574 & 8272288 & 11644050 & 23718912 & 19631968 \\
\hline 2010 & 4876716 & 7610327 & 19466419 & 31953462 & 23669719 \\
\hline 2011 & 6270783 & 11168241 & 21603753 & 39042777 & 28764701 \\
\hline 2012 & 9050286 & 14828830 & 24365828 & 48244944 & 38332712 \\
\hline 2013 & 11934912 & 16606009 & 18679779 & 47220700 & 48902340 \\
\hline 2014 & 12633536 & 21749842 & 19104512 & 53487890 & 54017114 \\
\hline 2015 & 14729110 & 19355489 & 33521025 & 67605624 & 60487542 \\
\hline 2016 & 17769405 & 17756720 & 42957103 & 78483228 & 63419185 \\
\hline 2017 & 17926882 & 19932952 & 43751195 & 81611029 & 71035168 \\
\hline
\end{tabular}

Sumber: Bursa Efek Indonesia

Perubahan pada data tabel IV.1 menunjukan nilai atau nominal penerimaan dana pihak ketiga dari tahun ketahun relative mengalami kenaikan yang berarti disertai dengan penyaluran kredit mengikuti kenaikan sesuai dengan dana yang dihimpunnya yakni dari dari dana pihak ketiga salah satunya, dapat disimpulkan kondisinya adalah selalu menaik atau terjadi kenaikan dari tahun ketahun selama 12 tahun terakhir.

\subsubsection{Analisis Verifikatif}

Dalam melakukan penelitian penyaluran kredit melalui kontribusi dana pihak ketiga pada Bank BJB periode 2006 - 2017, penulis menggunakan Uji asumsi klasik, uji Regresi sederhana, Uji koefisien korelasi, uji koefisien determinasi, serta pengujian hipotesis. Pengujian tersebut dilakukan dengan bantuan software SPSS dan untuk lebih jelasnya adalah sebagai berikut :

A. Uji Asumsi Klasik

Sebelum dilakukan pengujian hipotesis menggunakan analisis regresi sederhana, ada beberapa asumsi yang harus terpenuhi agar kesimpulan dari analisis regresi sederhana tersebut tidak bias. Diantaranya adalah uji normalitas, uji heteroskedastisitas, uji autokorelasi.

1. Uji Normalitas

Tabel IV.2

Hasil Pengujian Normalitas

One-Sample Kolmogorov-Smirnov Test

\begin{tabular}{|ll|r|r|}
\hline & \multicolumn{1}{|c|}{$\begin{array}{c}\text { Dana Pihak } \\
\text { Ketiga }\end{array}$} & \multicolumn{1}{c|}{$\begin{array}{c}\text { Kenyaluran } \\
\text { Kredit }\end{array}$} \\
\hline N & Mean & 12 & 12 \\
Normal & $4.3478 \mathrm{E}+07$ & $3.7458 \mathrm{E}+07$ \\
Parameters ${ }^{\mathrm{a}, \mathrm{b}}$ & Std. Deviation & $2.35143 \mathrm{E}+07$ & $2.13615 \mathrm{E}+07$ \\
Most Extreme & Absolute & .133 & .158 \\
Differences & Positive & .133 & .158 \\
& Negative & -.117 & -.121 \\
Kolmogorov-Smirnov Z & .461 & .547 \\
Asymp. Sig. (2-tailed) & .984 & .926 \\
\hline
\end{tabular}

a. Test distribution is Normal.

b. Calculated from data.

Sumber : Hasil pengolahan SPSS

Berdasarkan tabel IV.2 dapat terlihat bahwa nilai asymptotic significance variable dana pihak ketiga dan penyaluran kredit sebesar 0,984 dan 0,926 lebih besar dari nilai signifikansi 0,05, maka dapat disimpulkan data yang disajikan adalah berdistribusi normal.

2. Uji Heteroskedastisitas 


\section{Scatterplot}

\section{Dependent Variable: Penyaluran Kredit}

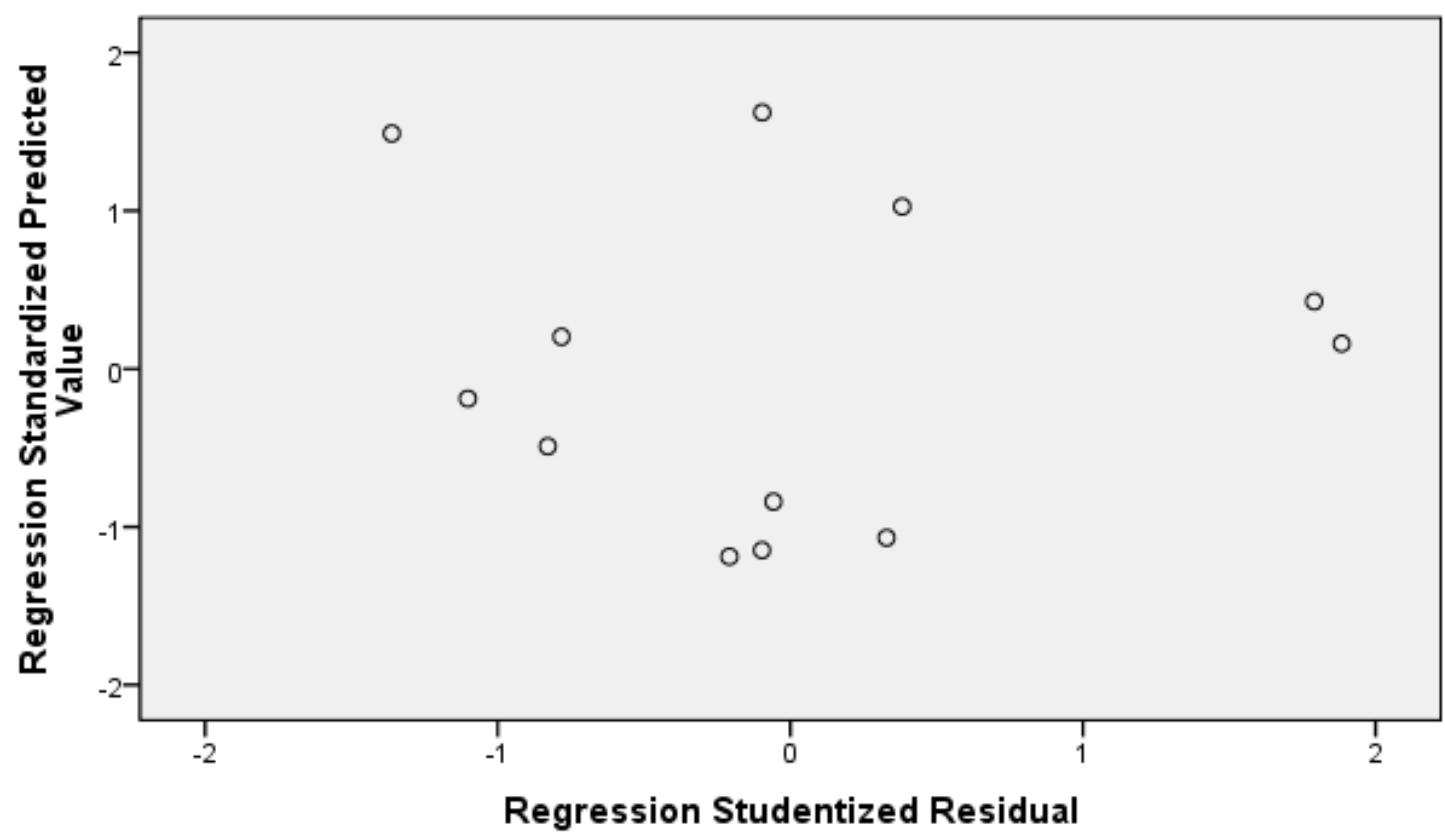

Grafik Scatterplot

Gambar IV.1

Berdasarkan gambar IV.1 dapat dilihat bahwa sebaran data menyebar tidak beraturan, sehingga kondisi tersebut dapat disimpulkan bahwa tidak terjadi gejala heteroskedastistas

3. Uji Autokorelasi

Untuk mengetahui apakah dalam model regresi terdapat korelasi antara data penelitian yang diurutkan berdasarkan waktu (data berkala). Pengujian ini menggunakan Durbin-Watson (DW).

\section{Tabel IV.3}

Nilai Durbin-Watson untuk uji Autokorelasi

\begin{tabular}{|c|c|c|c|c|c|}
\hline \multicolumn{6}{|c|}{ Model Summary ${ }^{b}$} \\
\hline Model & $\mathrm{R}$ & R Square & $\begin{array}{l}\text { Adjusted R } \\
\text { Square }\end{array}$ & $\begin{array}{c}\text { Std. Error of the } \\
\text { Estimate }\end{array}$ & Durbin-Watson \\
\hline 1 & $.980^{\mathrm{a}}$ & .960 & .956 & $4.50445 E+06$ & 1.271 \\
\hline
\end{tabular}

a. Predictors: (Constant), Dana Pihak Ketiga

b. Dependent Variable: Penyaluran Kredit

Sumber : Hasil pengolahan SPSS

Berdasarkan analisis data penyaluran kredit tabel IV.3 ternyata koefisien Durbin-Watson besarnya 1,271 melebihi 1 dan di bawah 3. Dengan demikian, dapat disimpulkan bahwa dalam regresi antara variabel bebas dana pihak ketiga terhadap penyaluran kredit tidak terjadi autokorelasi.

\section{B. Uji Koefisien Korelasi}

Analisis kolerasi bertujuan untuk mengukur kekuatan asosiasi (hubungan) linear antara dua variabel. Korelasi juga tidak menunjukkan hubungan fungsional. Dengan kata lain, analisis kolerasi tidak membedakan antara variabel dependen dan variabel independen. 
1. Koefesien korelasi antar dana pihak ketiga dan penyaluran kredit dapat dilihat sebagai berikut:

Tabel IV.4

Koefesien Korelasi dana pihak ketiga dan penyaluran kredit

\begin{tabular}{|l|r|r|r|r|r|}
\hline \multicolumn{1}{|c|}{ Model Sum mary $^{\text {b }}$} \\
\hline 1 & R & R Square & $\begin{array}{c}\text { Adjusted R } \\
\text { Square }\end{array}$ & $\begin{array}{c}\text { Std. Error of the } \\
\text { Estimate }\end{array}$ & Durbin-Watson \\
\hline
\end{tabular}

a. Predictors: (Constant), Dana Pihak Ketiga

b. Dependent Variable: Penyaluran Kredit

Sumber : Hasil pengolahan SPSS

Berdasarkan analisis data tabel IV.4 dapat dideskripsikan sebagai berikut:

Hubungan dana pihak ketiga dan penyaluran kredit adalah sebesar 0,980 dan mempunyai arti hubungan sangat kuat dan positif

\section{Koefisien Determinasi}

Untuk nilai koefisien determinasi dapat dilihat penyaluran kredit tabel IV.4 yang telah dihitung menggunakan program SPSS, tepatnya dilihat dari $\mathrm{R}$ Square yaitu sebesar 0,960 sehingga hasil perhitungan pengaruh atau determinasi dana pihak ketiga terhadap penyaluran kredit adalah sebesar 0,960 atau $96 \%$

\section{Pengujian Hipotesis}

1. Hasil Analisis Regresi

Tabel IV.5

Hasil Regresi

\section{Coefficients $^{a}$}

\begin{tabular}{|c|c|c|c|c|c|c|}
\hline \multirow[b]{2}{*}{ Model } & & \multicolumn{2}{|c|}{ Unstandardized Coefficients } & \multirow{2}{*}{$\begin{array}{c}\begin{array}{c}\text { Standardized } \\
\text { Coefficients }\end{array} \\
\text { Beta }\end{array}$} & \multirow[b]{2}{*}{$\mathrm{t}$} & \multirow[b]{2}{*}{ Sig. } \\
\hline & & B & Std. Error & & & \\
\hline \multirow[t]{2}{*}{1} & (Constant) & -1233093.074 & 2827930.104 & & -.436 & .672 \\
\hline & Dana Pihak & .890 & .058 & .980 & 15.407 & .000 \\
\hline
\end{tabular}

a. Dependent Variable: Penyaluran Kredit

Sumber : Hasil pengolahan SPSS versi 20

Untuk dapat mengetahui apakah terdapat pengaruh masing variabel bebas yakni dana pihak ketiga terhadap penyaluran kredit di Bank BJB. Berdasarkan analisis data hasil perhitungan coefficients abel IV.5 dapat dibentuk persamaan regresi linier berganda sebagai berikut :

Penyaluran Kredit $=-1233093.074+0.890$ Dana Pihak Ketiga

Analisis persamaan regresi berganda tersebut dijelaskan sebagai berikut:

a. Nilai negatif diasumsikan bahwa tanpa ditambahkan variabel dana pihak ketiga maka nilai Penyaluran kredit akan mengalami kenaikan atau peningkatan sebesar -1233093.074

b. Apabila $\mathrm{X}$ (dana pihak ketiga) mengalami peningkatan sebesar 1 satuan dengan asumsi maka penerimaan penyaluran kredit akan meningkat sebesar 0.890 .

c. Apabila $\mathrm{X}$ bernilai 0, maka penyaluran kredit besarnya sama dengan nilai konstanta. Itu berarti penyaluran kredit dipengaruhi oleh faktor lain diluar variabel bebasnya.

2. Hasil Pengujian hipotesis

Pengujian secara parsial dilakukan untuk mengetahui pengaruh masing masing variabel independen terhadap variabel dependen. Dapat dilihat sebagaimana dalam tabel berikut:

a. Pengaruh dana pihak ketiga terhadap penyaluran kredit

Berdasarkan tabel IV.5 dapat dilihat bahwa nilai. Statistik uji yang digunakan penyaluran kredit adalah uji t, nilai tabel yang digunakan sebagai nilai kritis penyaluran kredit (uji t) sebesar 15,407 
yang diperoleh dari tabel t penerimaan pajak daeraha $\alpha=0,05$ dan derajat bebas 1 untuk pengujian dua pihak. Nilai statistik uji t yang digunakan penyaluran kredit dan atau dengan pengujian nilai sig yg harus lebih kecil dari 0.05 , hasil yang didapat nilai sig $0.000<0.05$, sehingga kesimpulan dana pihak ketiga mempunyai pengaruh yang signifikan terhadap penyaluran kredit.

\subsection{Pembahasan}

\subsubsection{Dana Pihak Ketiga dan Penyaluran Kredit Bank BJB}

Dana pihak ketiga merupakan faktor utama bagi bank dalam penyaluran kredit, data yang didapat dari hasil penelitian selama kurun waktu 2010-2017 adalah sebagai berikut:

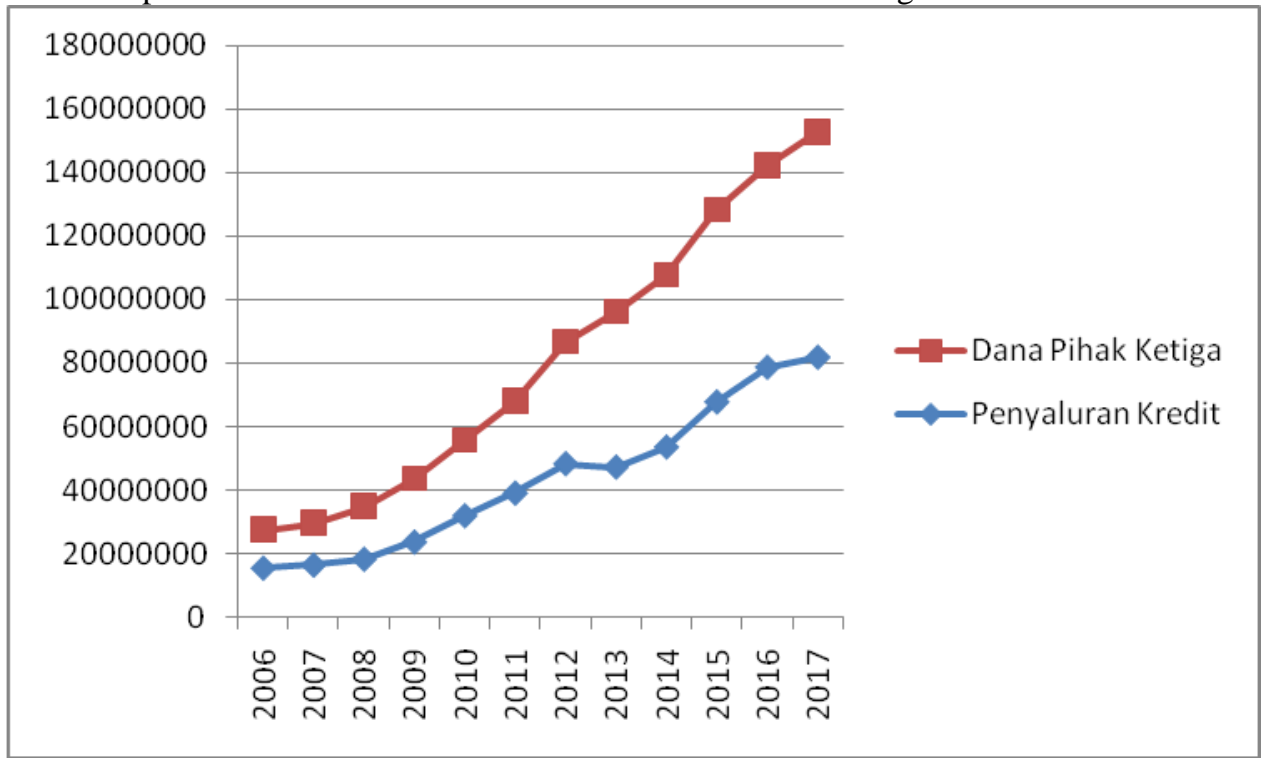

Gambar IV.2

Grafik Variable dan Perubahannya

Keadaan penyaluran kredit dapat dilihat pada tabel IV.1 cenderung terus menerus mengalami kenaikan dengan dengan didukung oleh peningkatan dana pihak ketiga yang secara bersama-sama selalu meningkat pula dari tahun ke tahun meskipun kenaikannya tidak diikuti dengan kenaikan yang konsisten. Perubahan prosentase kenaikan dpk dari tahun ke tahun diharapkan dapat menunjang kebijakan bank dalam penyaluran kembali dananya kepada masyarakat dalam bentuk kredit, meskipun ditahun 2012 ke tahun 2013 mengalami penurunan tetapi minat dari masyarakat atas produk kredit bank BJB terus meningkat. Perubahan dalam penggunaan dana untuk melakukan kredit tersebut dapat ditilik lebih dalam dengan penilaian secara kontribusi pernilai, dapat dilihat pada table sebagai berikut:

Tabel IV.6

Data Variable dan Kontribusi

\begin{tabular}{|c|c|c|}
\hline Total DPK & Penyaluran Kredit & $\begin{array}{c}\text { Penggunaan } \\
(\%)\end{array}$ \\
\cline { 1 - 2 } (dalam jutaan rupiah) & (dalam jutaan rupiah) & 75.69 \\
\hline 15540826 & 11763535 & 79.15 \\
\hline 16485382 & 13047515 & 89.55 \\
\hline 18347050 & 16429069 & 82.77 \\
\hline 23718912 & 19631968 & 74.08 \\
\hline 31953462 & 23669719 & 73.67 \\
\hline 39042777 & 28764701 & 79.45 \\
\hline 48244944 & 38332712 & 103.56 \\
\hline 47220700 & 48902340 & \\
\hline
\end{tabular}




\begin{tabular}{|c|c|c|}
\hline 53487890 & 54017114 & 100.99 \\
\hline 67605624 & 60487542 & 89.47 \\
\hline 78483228 & 63419185 & 80.81 \\
\hline 81611029 & 71035168 & 87.04 \\
\hline
\end{tabular}

Penggunaan dana masyarakat yang dikategorikan dana pihak ketiga memiliki prosentase penggunaan yang mencapai $>72 \%$ untuk melakukan penyaluran kredit, bahkan di tahun 2013 dan 2014 kredit yang disalurkan oleh bank BJB nilainya memakai lebih dari 100\% dana yang dihimpun oleh bank dalam bentuk tabungan, giro dan deposito.

\subsubsection{Pengaruh Dana Pihak Ketiga Terhadap Penyaluran Kredit}

Berdasarkan hasil penelitian tentang besarnya pengaruh dana pihak ketiga terhadap penyaluran kredit adalah 0,960 atau 96\% dengan arah positif dengan tingkat signifikan sebesar 0,000<0,050 dan diperoleh nilai yang signifikan pengaruhnya, dengan nilai $4 \%$ factor lain yang tidak dihitung dalam penelitian ini.

Penelitian ini menunjukan betapa kuatnya pengaruh dana pihak ketiga terhadap penyaluran kredit. Hal tersebut terjadi karena dana pihak ketiga yang dihimpun oleh pihak bank merupakan landasan atau kekuatan dari pihak bank dalam mengsilkan pendapatan bunga dengan menyalurkan kredit kepada masyarakat pula, maka semakin tinggi dana pihak ketiga yang dihimpun oleh bank, maka semakin tinggi kemampuan bank dalam menghasilkan pendapatan dengan produk kreditnya. Hasil penelitian menegaskan yang telah diteliti oleh (Andhika, 2013) menyatakan pertumbuhan kredit secara parsial berpengaruh positif pada kinerja operasional

\section{KESIMPULAN}

Berdasarkan hasil penelitian dan pembahasan variabel penelitian mengenai penyaluran kredit melalui eksistensi dana pihak ketiga Bank BJB, maka dapat ditarik kesimpulan sebagai berikut:

1. Keadaan pendapatan dana pihak ketiga dari tahun 2006 - 2017 mengalami kenaikan dari tahun ketahun yang menjadikan dana awal untuk operasional bank semakin meningkat, meskipun ada penurunan di tahun 2012-2013.

2. Penyaluran kredit mempunyai dampak dari peningkatan tiap tahun dana pihak ketiga, sehingga kemampuan penyaluran kredit dari tahun ketahun semakin meningkat sesuai dengan keadaan inflasi terkini.

3. Kontribusi serta pengaruh yang terima oleh penyaluran kredit atas dana yang dihimpun dari pihak ketiga selama tahun 2006-2017 mendapat pengaruh yang kuat dari tahun ketahun, dalam artian perubahan dana pihak ketiga akan menunjang bank dalam menghasilkan pendapatan bunga atas penyaluran kredit yang dilakukan.

\section{UCAPAN TERIMA KASIH}

Berdasarkan hasil penelitian yang telah dilakukan, maka penulis mengucapkan kepada semua pihak terkait yang telah membantu dan memperlancar penyelesaian penelitian ini. Penulis mengucapkan terimakasih yang sebesar-besarnya kepada pihak BEI Jawa Barat, BPS Jawa Barat, seluruh rekan-rekan di Universitas BSI, keluarga serta pihak-pihak lain yang tidak bisa disebutkan satu persatu. Selanjutnya penulis juga memberikan saran yang diharapkan akan bermanfaat bagi instansi terkait, dan bagi para peneliti yang ingin meneliti tentang tema yang sama dengan penilitian ini. Adapun saran tersebut adalah sebagai berikut :

1. Diharapkan instansi yang terkait dengan penyaluran kredit bisa memberikan solusi bagi para pelaku kegiatan perbankan untuk mengembangkan usahanya sehingga meningkatkan perekonomian Indonesia.

2. Bagi peneliti selanjutnya, diharapkan agar dapat melakukan pengembangan penelitian ini sehingga dapat menambah wawasan dan pengetahuan tentang akuntansi.

\section{DAFTAR PUSTAKA}


Andhika, Putu Bayu dan Sujana, I Ketut. 2016. Pengaruh Pertumbuhan Kredit, Dana Pihak Ketiga dan Aplikasi Sistem Informasi Akuntansi Pada Kinerja Operasional. ISSN 23028556. Bali: E-Jurnal Akuntansi Universitas Udayana:777-804. Diambil dari: http://ojs.unud.ac.id/index.php/Akuntansi/article/viewFile/14228/12556 (8Januari2017)

Ikatan Bankir Indonesia (IBI) dan Lembaga Sertifikasi Profesi Perbankan (LSPP). 2013. Memahami Bisnis Bank. Jakarta: PT. Gramedia Pustaka Utama.

Kasmir. 2012. Manajemen Perbankan. Jakarta: PT. RajaGrafindo Persada.

Kasmir. 2015. Bank dan Lembaga Keuangan Lainnya Edisi Revisi 2014. Jakarta: PT. RajaGrafindo Persada.

Latumaerissa, Julius R. 2014. Manajemen Bank Umum. Jakarta: Mitra Wacana Media.

Baihaqi, Muhamad Bari. 2016. BI Catat Penyaluran Kredit Bank Tumbuh 8,4\% Diambil dari: http://www.neraca.co.id/article/68944/bi-catat-penyaluran-kredit-bank-tumbuh-84 (8Januari 2017).

Pratin dan Adnan, Akhyar. 2005. Analisis Hubungan Simpanan, Modal Sendiri, NPL, Prosentase Bagi Hasil dan Mark Up Keuntungan Terhadap Pembiayaan Pada Perbankan Syariah Studi Kasus Pada Bank Muamalat Indonesia (BMI). ISSN 1410-9018. Yogyakarta: Sinergi Edisi Khusus On Finance: 35-52. Diambil dari: http://s3.amazonaws.com/academia.edu.documents/43419595/937-9241PB.pdf?AWSAccessKeyId=AKIAJ56TQJRTWSMTNPEA\&Expires=1476634161\&Si gnature $=\% 2 \mathrm{~F} 1 \mathrm{El} 0 \mathrm{~N} 4 \mathrm{auG} 9 \mathrm{zSyBBFtaFTUpqTHA} \% 3 \mathrm{D} \&$ response-content disposition=inline\%3B\%20filename\%3DEdisi_Khusus_on_Finance_2005_Hal._35_52.pdf. (8Januari 2017).

Rivai, Sofyan Basir., Sudarto, Sarwono dan Veithzal, Arifiandy Permata. 2013. Commercial Bank Mangement: Manajemen Perbankan dari Teori ke Praktik. Jakarta: PT. RajaGrafindo Persada.

Sari, Greydi Normala. 2013. Faktor-Faktor yang Mempengaruhi Penyaluran Kredit Bank Umum di Indonesia (Periode 2008.1-2012.2). ISSN 2303-1174. Manado: Junal EMBA Vol.1 No.3: 931-941. Diambil dari: http://ejournal.unsrat.ac.id/index.php/emba/article/viewFile/2298/1852 (8 Mei 2016).

Sugiyono. 2014. Metode Penelitian Kombinasi (Mixed Methods). Bandung: Alfabeta

Undang-undang Nomor 10 Tahun 1998 tentang Perubahan Atas Undang-undang Nomor 7 Tahun 1992 tentang Perbankan(temu) 